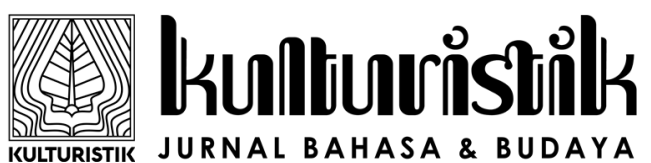

Vol. 3, No. 1, Januari 2019, 75-83

Available Online at https://ejournal.warmadewa.ac.id/index.php/kulturistik

DOI: dx.doi.org/10.22225/kulturistik.3.1.952

\title{
BAHASA INDONESIA DAN PERJUANGAN BANGSA
}

\author{
Ni Nyoman Kertiasih \\ Universitas Warmadewa \\ nnkertiasih@gmail.com
}

\begin{abstract}
ABSTRAK
Penelitian ini bertujuan untuk menjelaskan terbentuknya bahasa Indonesia sebagai bahasa nasional, untuk menjelaskan bahwa bahasa Indonesia merupakan salah satu alat perjuangan bangsa, dan untuk menjelaskan dampak bahasa Indonesia dalam kehidupan berbangsa yang anti colonial. Data penelitian ini adalah bahan tertulis yang ditulis pada masa perjuangan dan sesudah masa perjuangan mengusir penjajahan. Metode yang digunakan adalah metode kualitatif, deskriptif analitis, dipadu dengan metode analisis wacana kritis. Penelitian ini mengungkap bahwa bahasa Indonesia sejak awal kemunculannya di tahun 1928 sudah dimengerti sebagai bahasa alat perjuangan bangsa. Sebagai dampaknya, bahwa bahasa Indonesia telah mempengaruhi sikap masyarakat, bangsa dalam mengahadapi penjajahan. Masyarakat mulai menggalakkan penggunaan bahasa Indonesia di masyarakat, di sekolah, dan menggunakan bahasa Indonesia dalam berbagai pertemuan formal dan tidak formal. Masyarakat menentang menggunakan bahasa Belanda yang sebelumnya diwajibkan.
\end{abstract}

Kata kunci: bahasa Indonesia, bahasa nasional, perjuangan

\begin{abstract}
[Title: Indonesian language and the national struggle] This research aims to explain the formation of Indonesian as a national language, to explain that Indonesian is one of the tools of the nation's struggle, and to explain the impact of Indonesian in the life of an anti-colonial nation. The data of this study were written material written during the struggle and after the struggle to drive out colonialism. The method used were a qualitative, analytical descriptive method, combined with a critical discourse analysis method. This research reveals that Indonesian language since its inception in 1928 has been understood as the language of the tool of the nation's struggle. As a result, Indonesian language has influenced the attitude of the people, the nation in the face of colonialism. The community began to promote the use of Indonesian in the community, at school, and use Indonesian in various formal and informal meetings. People oppose using Dutch language that was previously required.
\end{abstract}

Keywords: Indonesian language, national language, struggle

\section{PENDAHULUAN}

Seperti diketahui, Bahasa Indonesia lahir merupakan bahasa perjuangan untuk mencapai Indonesia merdeka. Kelahiran Bahasa Indonesia tidak dapat dipisahkan dari usaha perjuangan tokoh-tokoh bangsa mendorong kesadaran berbangsa Indonesia untuk lepas dari cengkraman penjajahan. Di sini penduduk kepulauan masih hidup dengan sistem nilai budaya kesukuan, tetapi mulai tumbuh kesadaran untuk hidup bersama sebagai satu bangsa. Topik Bahasa Indonesia 
dan Perjuangan Bangsa, dimaksudkan untuk mencari pemahaman lebih jauh mengenai munculnya bahasa Indonesia berkaitan dengan gerak perjuangan bangsa menuju kemerdekaan.

Dapat dikatakan bahwa semangat berjuang itu bersumber pada adanya kesadaran berkebangsaan yang mulai tumbuh. Kesadaran kebangsaan baru muncul setelah kelompok-kelompok bangsa ini terjebak pada keadaan, kondisi yang memperihatinkan berada dibawah tekanan penjajahan asing (Belanda). Sebelumnya suku-suku bangsa yang menjadikan bangsa Indonesia, memiliki semangat kebangsaan yang sempit (kedaerahan): Jawa, Bali, Sumatera, Selebes, dll. Orang Jawa merasa berbeda dengan orang Bali, orang Madura orang Sumatera dan lainlain. Perang-perang suku atau perang etnis pun muncul di berbagai tempat di kepulauan Nusantara ini. Pertentangan antarsuku semakin merebak ketika hal itu didukung pula oleh kepentingan kolonialisme di dalamnya.

Kesadaran berkebangsaan baru muncul sejak tahun 1908 (20 Mei) dengan munculnya organisasi pemuda yang dikenal dengan Budi Utomo, berjuang untuk mencerdaskan bangsa. Semangat kebangsaan yang sempit dihapus. Semangat kebangsaan memuncak dengan diadakannya Kongres Pemuda tahun 1928 di Jakarta. Seluruh komponen bangsa yang berupa suku, daerah, agama, bertemu bersatu membangun semangat bersatu untuk satu bangsa Indonesia. Semua itu berdasarkan kesadaran diri, kehendak bersama untuk bersatu, hidup bersama menjadi satu bangsa, Negara bangsa Indonesia. Di sini kelompok-kelompok bangsa (berdasarkan etnik, daerah, suku, agama) lebur menjadi bangsa yang satu. Dalam kaitan itu, tulisan ini dibuat dengan maksud melihat Bahasa Indonesia sebagai satu symbol, factor penting dalam perjuangan bangsa menuju kemerdekaan Indonesia. Bahasa Indonesia penting dalam perjuangan mengusir penjajahan dari tanah Indonesia.

Kedudukan dan fungsi bahasa Indonesia juga penting dimengerti sebagai bahasa alat perjuangan menuju Indonesia merdeka (Amran, 1976). Karena itu, tulisan Amran Halim ini penting sebagai rujukan dalam menulis kajian ini. Koentjaranirat dalam tulisannya berjudul, "Pengembangan Bahasa Indonesia Sebagai Unsur Kebudayaan Nasional", dalam Bahasa dan Sastra, Tahun 1, No.2, Jakarta. Di sini Koentjaraningrat melihat bahasa sebagai "unsur sokoguru tiap kebudayaan". Tetapi Koentjaranirat mengeluhkan, walaupun bahasa Indonesia sudah diakui sebagai bahasa nasional, namun dalam penggunaannya tampak belum baik, kurang perhatian, sehingga dalam penggunaannya, bahasa Indonesia masih dicampur aduk dengan unsur-unsur bahasa lain (bahasa Jakarta, bahasa Jawa, bahasa Inggris, bahasa Belanda, dan lain-lain). Dengan begitu, bahasa Indonesia, seperti kurang mendapat perhatian, kurang pemeliharaan, dan karena itu dapat menggerogoti, menghambat perkembangan bahasa Indonesia itu sendiri. Karena itu, sarannya agar dilakukan pemeliharaan, pembinaan yang baik terhadap bahasa Indonesia (Koentjaranirat, 1975). Tulisan ini juga menarik menjadi gambaran perbandingan dalam penulisan kajian ini.

Abu Hanifah M.D, menulis dengan judul, Renungan Perjuangan Bangsa, Dulu dan Sekarang. Di sini Abu Hanifah memaparkan keadaan perjuangan bangsa Indonesia mengusir penjajahan Belanda, sejak lahirnya perkumpulan Budi Utomo, bulan Mei 1908 sampai perundingan dengan Belanda dalam Konferensi Meja Bundar (1949) (M.D, 1978). Abu Hanifah melihat betapa pentingnya peranan bahasa yang mempersatukan seluruh pemuda Indonesia dalam satu gerak langkah yang tegas, bergelora melaui Kongres Pemuda Indonesia II (28 Oktober 
1928). Tulisan ini juga memberi gambaran, betapa pentingnya peranan bahasa (bahasa kesatuan Indonesia) dalam perjuangan mengusir penjajahan. Karena itu, tulisan ini berguna dalam melakukan kajian daam penulisan ini.

I Wayan Bawa, menulis buku dengan judul, Sejarah, Fungsi, dan Kedudukan Bahasa Indonesia. Denpasar. Di sini Wayan Bawa tampak menulis dengan pendekatan sejarah, menyampaikan bagaimana bahasa Indonesia tumbuh, berkembang, memenuhi fungsi, dan kedudukannya sebagai bahasa persatuan Indonesia, bahasa nasional Indonesia (Bawa, 1980). Dengan demikian, Wayan Bawa dalam karyanya memberikan gambaran yang lengkap mengenai perkembangan dan fungsi bahasa Indonesia, yang juga sebagai alat perjuangan bangsa. Sebagai gambaran sejarahnya, dielaskan bahwa bahasa Indonesia dalam perkembangannya dari periode sebelum lahirnya, periode sekitar lahirnya dan periode setelah lahirnya sebagai bahasa kesatuan Indonesia (hal.3). Dengan gambaran pemaparan demikian, maka buku karya Wayan Bawa ini pantas menjadi rujukan dalam menulis kajian ini dan relevan digunakan terutama dalam melihat bahasa Indonesia sebagai alat perjuangan bangsa.

Robert Sibarani (2008), menulis dengan judul, "Pelestarian Bahasa dan Aksara sebagai Jatidiri dalam Meningkatkan Kesejahteraan Masyarakat", dalam Kenedi Nurhan (ed.) Industri Budaya, Budaya Industri. Jakarta (hal.639-652). Mengawali tulisannya, Robert mulai dengan memaparkan adanya dua fungsi bahasa, yakni: fungsi komunikatif dan fungsi simbolik..Di sini fungsi simbolik bahasa, menyangkut fungsi bahasa sebagai lambang kelompok, sebagai symbol, bahkan sebagai wahana berkumpul. Bahkan bahasa menjadi sangat penting dalam sentiment etnik dan sentiment nasional, karena daya simbolismennya yang sangat kuat dan jelas, disamping aspek komunikatifnya (Sibarani, 2008). Maka karya Robert Sibarani menjadi penting sebagai rujukan pula dalam menulis kajian ini.

Maka pertanyaan-pertanyaan yang dapat diajukan adalah: (1) Bagaimana munculnya bahasa Indonesia menjadi bahasa nasional Indonesia? (2) Bagaimana bahasa Indonesia menjadi alat perjuangan bangsa melawan penjajahan? (3) Apa dampaknya dalam kehidupan berbangsa yang anti kolonial? Beberapa pertanyaan yang dituangkan di atas, akan coba dicari jawabannya dalam kajian penelitian ini dan diharap dapat memberikan manfaat bagi rasa persatuan dan kesatuan bangsa Indonesia.

\section{METODE}

Mengenai bahan-bahan yang digunakan dalam kajian ini, adalah berupa bahan tertulis yang ditulis pada masa perjuangan atau sesudah masa perjuangan mengusir penjajahan. Berkaitan dengan metode, dapat disebutkan bahwa di sini digunakan metode kualitatif, deskriptif analitis, dipadu dengan metode analisis wacana kritis. Dengan metode kualitatif dimaksudkan suatu penelitian yang analisisnya didasarkan pada keterangan, informasi yang isinya dipahami secara kualitatif. Berbagai informasi, keterangan akan dikaji, dipahami, analisis secara kritis untuk menemukan makna yang terdapat di dalamnya. yang dapat memberikan arti pada bahasa Indonesia, sebagai symbol perjuangan melawan penjajahan. Bahanbahan itu, di antaranya: H.Noeng Muhadjir (2002), Metodologi Penelitian Kualitatif. Yogyakarta: Penerbit Rake Sarasin; H.M.Burhan Bungin (2010). Penelitian Kualitatif. Komunikasi, Ekonomi, Kebijakan Publik, dan Ilmu Sosial lainnya. Jakarta. 


\section{PEMBAHASAN}

\section{Dari Bahasa Melayu ke Bahasa Indonesia}

Sebelum mencapai kemerdekaan, bangsa Indonesia hidup dalam suku-suku dengan bahasa, budaya dan nilai-nilainya masing-masing. Tiap suku hidup sebagai satu komunitas yang otonum, berdiri sendiri dalam sistem kemasyarakatannya. Tiap suku memiliki cara hidupnya sendiri, seperti: Suku Jawa dengan Bahasa dan budaya Jawanya, Bali dengan Bahasa dan budaya Balinya, Lombok dengan Bahasa dan budaya Sasaknya, suku Makasar dengan Bahasa Makasarnya, suku Melayu dengan Bahasa Melayunya, dan sebagainya. Mereka hidup bersukusuku, memiliki sejarah dan budayanya masing-masing, di lingkungan territorial yang dipisahkan oleh hamparan laut yang luas di Kepulauan Nusantara. Mengenai Bahasa, tiap suku memiliki bahasa atau lambang-lambangnya masingmasing untuk dapat mengerti dalam berhubungan satu dengan yang lain. Apabila berhubungan antar suku sering terjadi penggunaan tanda-tanda, seperti: mengangkat tangan, menggelengkan kepala, atau mengangguk untuk menyatakan penolakan atau persetujuan. Itu hampir biasa terjadi seperti di dalam konteks berinteraksi antara dua atau lebih orang yang saling tidak mengerti bahasanya satu dengan yang lain.

Kemudian dalam keadaan yang lebih maju, penggunaan bahasa sebagai perantara menjadi penting di kepulauan. Hubungan perdagangan antar pulau, yang sekali gus juga berarti antarsuku yang berbeda bahasa, para pedagang banyak menggunakan Bahasa Melayu. Menurut riwayatnya, disebut ciri--ciri Melayu yang sebenarnya adalah bangsa yang suka mengembara, tidak suka diam dalam satu tempat, aktif bergerak, karena dalam tubuh mereka turun temurun mengalir darah peengembara, petualang, perantau. "Suatu suku bangsa di Nusantara yang senantiasa dalam proses pengembaraan dan pertualangan, berdagang dan merantau, selalu hendak keluar dari kampung halaman sendiri .." (Zuber Usman, 1975: 8). Kata "malayu", sekarang sering diucapkan "melayu" berasal dari kata "malaya", kependekan dari kata "hima alaya", yang berarti: hima = salju, alaya = tempat, dan kemudian menjadi Himalaya = tempat salju. Bangsa Melayu yang sesungguhnya awalnya datang dari Mongolia, menyebrangi Selat Malaka, mendarat di Pulau Sumatera. Dari nenek moyang mereka suka mengembara, kemudian keturunan mereka menyebar ke seluruh Nusantara, bahkan meluas sampai ke Lautan Teduh (Pasifik) dan pulau-pulau di Hawai (Usman, 1975: 9).

Tampaknya, Bahasa Melayu merupakan bahasa yang mudah dimengerti, sehingga biasa digunakan oleh para pedagang yang lewat di kepuauan. Hubungan perdagangan antarpulau yang ramai membawa mereka kerap kali harus mampu saling menyapa dan mengerti satu sama lain, dan bahasa dari orang-orang Melayu banyak digunakan. Dalam perjalanan merantau yang panjang dari suku Melayu, secara perlahan Bahasa Melayu menjadi banyak digunakan, baik oleh orangorang bukan orang Melayu, maupun orang asing yang datang di kepulauan. Penggunakan Bahasa Melayu yang semakin banyak, menyebabkan Bahasa Melayu kemudian menjadi bibit/embrio bagi berkembannya Bahasa Indonesia. Bahasa Melayu menjadi "Lingua Franca", bahasa penghubung dalam pergaulan sukusuku bangsa di Nusantara, yang semakin lama semakin meluas di kalangan penduduk. Bahasa Melayu berfungsi sebagai alat komunikasi masyarakat Nusantara yang lalu lalang di kepulauan, berbicara antar orang-orang dari kelompok budaya yang berbeda. Atas komunikasi yang semakin intensif antar penduduk di kepulauan, lama kelamaan bahasa Melayu itu menjadi banyak digunakan, 
kemudian menjadi benih bahasa Indonesia yang akan tumbuh. Begitu bahasa menjadi alat komunikasi antar penduduk, juga bahasa Indonesia menjadi alat komunikasi dalam rangka perjuangan melawan penjajahan.

\section{Bahasa Indonesia Sebagai Alat Perjuangan}

Di masa penjajahan, bangsa Indonesia diwajibkan menggunakan bahasa kolonial (Belanda) dalam berkomunikasi dalam hubungan pergaulan. Anak-anak sekolah mulai diajarkan menggunakan bahasa Belanda dalam berkomunikasi. Buku-buku pelajaran di sekolah dicetak menggunakan bahasa Belanda. Namun kemudian tumbuh tokoh-tokoh bangsa yang menyadari keadaan demikian, dan berusaha mensosialisasikan bahasa sendiri untuk dipakai berkomunikasi. Perkumpulan Budi Utomo yang didirikan oleh Dr.Sutomo, para anggota dan murid-murid dianjurkan menggunakan bahasa Jawa untuk berkomuniksi. Kalau tidak, bahasa Melayu dapat digunakan. Maka dengan semakin majunya organisasi sebagai organisasi pergerakan, bahasa Jawa dan bahasa Melayu semakin banyak digunakan dalam berhubungan antar penduduk dari daerah yang berbeda.

Pada tahun 1928, tampak keadaan, semangat peruangan semakin matang. Para pemuda terpelajar dari berbagai daerah berpikir untuk dapat bersatu dalam satu kekuatan. Organisasi Pemuda kedaerahan, seperti: Jong Java, Jong Selebes, Jong Ambon, Jong Sumatera, dan lain-lain berkumpul memikirkan nasib bangsa. Kesadaran nasional semakin meluas di kalangan anak-anak muda terpelajar. Pada bulan Oktober 1928, diselenggarakan suatu kongres, Kongres Pemuda Indonesia di Jakarta. Ketika itu, tanggal 28 Oktober 1928 para pemuda berkumpul, berdiskusi memikirkan nasib bangsa. Tidak gampang pertemuan itu dilaksanakan, sebab pertemuan dilakukan di bawah pengawasan ketat dari pemerintah kolonial Belanda. Meski demikian, Kongres tetap dijalankan. Atas keberanian luar biasa dari pemuda, dapat dirumuskan, disepakati hasil yang membanggakan. Pertemuan itu menghasilkan kesepakatan, kebulatan tekad untuk bersatu sebagai satu bangsa. Demi mengikat rasa kebangsaan yang sedang bergeolak, maka para tokoh pemuda itu memunculkan kesepakatan dengan tiga ikrar, yang dikenal dengan "Sumpah Pemuda" dan menggunakan bahasa Indonesia sebagai perantaranya. Dalam sumpah itu dikumandangkan:

"Kami putera dan puteri putera dan puteri Indonesia, mengaku berbangsa satu, bangsa Indonesia. Kami putera dan puteri Indonesia, menjunjung Bahasa persatuan, Bahasa Indonesia" (Yayasan Gedung-gedung Bersejarah Jakarta, 1978).

Dengan diikrarkannya Sumpah Pemuda, maka para pemuda selain mengakui tanah air dan bangsa yang satu, yakni Indonesia, juga mengikrarkan Bahasa Indonesia, sebagai bahasa persatuan. Bahasa Indonesia harus dipertahankan sebagai Bahasa Persatuan, satu Bahasa yang menjadi symbol, semangat untuk bersatu padu membela dan mempertahankan kesatuan bangsa Indonesia. Demikian, Bahasa Indonesia dikumandangkan menjadi bahasa persatuan, symbol nasional Indonesia, yang asal-usulnya dari Bahasa Melayu. Dalam kiprahnya sebagai bahasa persatuan, maka bahasa Indonesia mulai digunakan sebagai alat komunikasi antar penduduk dari berbagai daerah yang berbeda di kepulauan. Ia membangun sentiment bangsa melawan penjajahan bangsa asing.

Dalam hubungan penggunaan bahasa Indonesia sebagai alat komunikasi tidak sedikit hambatan yang dialami. Selain karena kurangnya perhatian, karena 
belum lama dinyatakan sebagai bahasa persatuan, tetapi juga karena kurangnya usaha pembelajaran, atau karena adanya tekanan dari pemerintah kolonial Belanda. Dalam hubungan itu, Koentjaraningrat mengatakan antara lain.

"Di luar waktu kerja, di saat-saat mendengarkan pidato, atau di luar saat kita mengadakan pembicaraan yang bersifat resmi pada pertemuan, kita orang Indonesia menggunakan bahasa daerah, bahasa Jakarta, bahasa Belanda-Indonesia, ataupun bahasa Indonesia-Khas yang tercampur dengan kata-kata Belanda, serta potongan-potongan kalimat bahasa Inggris" (Koentjaranirat, 1975: 2).

Tampaknya, di sini Koentjaraningrat memahami bahasa Indonesia itu sebagai bahasa persatuan yang dicetuskan dalam Kongres Pemuda tahun 1928 itu, belum mampu menjadi alat komunikasi yang baik, sebagai bahasa nasional yang anti imperialisme. Wayan Bawa menulis, "Lahirnya bahasa Indonesia sebagai bahasa persatuan, merupakan akibat wajar dari watak nasionalisme yang anti imperialisme Belanda, karena bahasa Belanda adalah bahasa Imperialis. Karena itu, lahirnya bahasa Indonesia tidak jauh dari watak lahirnya nasionalisme Indonesia" (Bawa, 1980: 8). Apabila lahirnya semangat, kesadaran nasional dapat dimengerti sejalan dengan berdirinya Budi Utomo (1908), maka semangat anti penjajahan terorganisasi mulai di tahun itu, dan penggunaan bahasa Belanda (kolonial) dikritisi. Di sana perkumpulan Budi Utomo menggalakkan penggunaan bahasa-bahasa pribumi, Jawa atau Melayu, digunakan perantara dalam berkomunikasi satu dengan yang lain. Semangat anti kolonial mengerucut di dalam Kongres Pemuda tahun 1928, dengan dicetuskannya "Sumpah Pemuda" dengan tiga ikrar, yang salah satunya, menyatakan berbahasa satu bahasa Indonesia. Di sini bahasa Indonesia tumbuh menjadi bahasa persatuan bangsa (nasional) Indonesia, anti kolonial, imperialisme.

Selanjutnya diketahui betapa di pihak pemerintah kolonial berusaha menghalangi penggunakan bahasa Indonesia di kalangan penduduk. Hal itu terutama dialami oleh kelompok pemuda yang tergabung dalam organisasi pergerakan, untuk menggunakan bahasanya sendiri, bahasa Indonesia. Sebagai contoh dapat disampaikan, hambatan bagi pemuda pada organisasi Indonesia Muda (IM), dilarang menggunakan bahasa Indonesia. Di sini organisasi Indonesia Muda (IM) merupakan fusi dari berbagai organisasi gerakan pemuda seperti: Jawa, Sunda, Sumatera, Sulawesi, Minahasa, Ambon. Itu terjadi di tahun 1930-an (Kamajaya dalam Yayasan Gedung-gedung Bersejarah Jakarta, 1978: 99).

Jelas kutipan di atas menunjukkan betapa bahasa Indonesia menjadi symbol, alat perjuangan bangsa untuk persatuan, yang perlu selalu diperhatikan, dibina, dan digunakan sebaik-baiknya. Tentu hal itu dimaklumi, sehingga kemudian semakin diusahakan diadakan pembelajaran untuk memperbaiki bahasa Indonesia sebagai bahasa nasional. Di sini bahasa Indonesia, selain berfungsi sebagai alat komunikasi, juga berfungsi sebagai symbol alat perjuangan dari kesatuan bangsa Indonesia merdeka.

\section{Pengaruh Bahasa Indonesia Dalam Kehidupan Bangsa}

Berbicara pengaruh dari dari bahasa Indonesia yang dikumandangkan sebagai bahasa persatuan, tentu tidak kecil. Kesepakatan, sumpah para pemuda menetapkan bahasa Indonesa sebagai bahasa persatuan, symbol bangsa Indonesia, memperlihatkan pengaruhnya yang besar dan kuat di masyarakat. Bahasa Indone- 
sia semakin meluas, digunakan oleh masyarakat, terutama para pemuda pergerakan yang merasa wajib menyebarluaskan, meskipun terjadi tekanan dari pihak pemerintah Belanda. Dalam situasi masih dalam keadaan terjajah, penggunaan bahasa Indonesia tetap diawasi oleh pemerintah Belanda. Pengaruhnya besar pada para pemuda yang sudah menyadari betapa pentingnya gerakan perjuangan yang dijiwai oleh semangat Sumpah Pemuda, 28 Oktober 1928. Para pemuda merasa bangga dapat menggunakan bahasa Indonesia.

Pernah terjadi pada suatu peristiwa, para pemuda dalam rencana pementasan satu lakon sandiwara "Untung Surapati" harus menggunakan bahasa Belanda, tidak diperbolehkan menggunakan bahasa Indonesia. Itu artinya, bahasa Indonesia dianggap berbahaya bagi wibawa pemerintah kolonial. Berdekatan dengan peristiwa itu, diadakan pertemuan aksi sosial Indonesia Muda (1932) dihadiri oleh tokoh-tokoh pemuda dan menggunakan bahasa Indonesia. Ketika rapat dibu$\mathrm{ka}$, belum ada 10 menit tiba-tiba polisi (dinas intel pemerintah) mengetok-ngetok pintu, agar rapat segera dibubarkan. Semua terkejut dengan kejadian itu dan bangun berdiri untuk mengambil langkah. Pimpinan rapat berdiri terpaku di atas mimbar, penuh tanda tanya. "mungkin katakutan juga". Namun tiba-tiba seperti terjadi ilham, entah dari mana datangnya, lalu "semua berdiri dan serentak menyanyikan lagu Indonesia Raya, dengan penuh semangat". Saat itu, sang polisi juga berdiri tegak, tetapi segera meninggalkan tempat (Kamajaya dalam Yayasan Gedung-gedung Bersejarah Jakarta, 1978: 100-101).

Kamajaya masih menulis, bahwa pada tahun 1933 ketua IM cabang Yogyakarta, Sutomo, diaukan ke pengadilan karena delik pers. Ia menolak diperiksa menggunakan bahasa Belanda, lalu pemeriksaan dilakukan dalam bahasa Indonesia. Juga di tahun 1936 ketika terjadi pengaduan atas sebuah pemberitaan di harian "Sedya Tama" Yogyakarta, presiden Landraad Belanda terpaksa menggunakan bahasa Indonesia dalam pemeriksaannya (Kamajaya dalam Yayasan Gedunggedung Bersejarah Jakarta, 1978: 102).

Guru-guru dan anak-anak di sekolah juga semakin terpengaruh untuk menggunakan bahasa Indonesia. Para siswa di sekolah Taman Siswa misalnya merubah cara berbahasanya, dengan menggunakan bahasa Indonesia. Panggilan Bapak dan Ibu kepada guru-guru mulai dibiasakan. Di Sekolah Taman Siswa, sementara sekolah-sekolah lainnya masih menggunakan bahasa Belanda, "Meneer" untuk bapak dan "Yuffrouw" untuk ibu (Sutopo dalam Yayasan Gedung-gedung Bersejarah Jakarta, 1978: 177). Cara-cara semacam itu semakin luas berpengaruh di kalangan masyarakat.

Kemudian saat-saat menjelang kemerdekaan, penggunaan bahasa Indonesia semakin meluas, lebih-lebih setelah kedatangan Jepang di Indonesia, bahasa kolonial Belanda didesak tidak diberlakukan lagi. Pada masa itu, dengan sendirinya bahasa pribumi Indonesia semakin bermanfaat, digunakan di kalangan masyarakat, meskipun bahasa Jepang mulai dimasukkan ke masyarakat Indonesia. Bahasa Indonesia semakin meluas mempengaruhi masyarakat Indonesia, dan tokoh-tokoh bangsa selalu menggunakan itu dalam berbagai kesempatan berbahasa. Hal itu terbukti ketika diadakan Sidang Badan Penyelidik Usaha Kemerdekaan Indonesia (BPUPKI) dan Panitia Persiapan Kemerdekaan Indonesia (PPKI) yang berada di bawah kekuasaan pemerintah kolonial Jepang, di bulan Mei-Juni tahun 1945. Sidang itu dijalankan di bawah pengawasan pemerintah Jepang. Sidang membicarakan dasar-dasar Indonesia merdeka. Sidang dipimpin oleh Ir.Sukarno sebagai ketua panitia dengan menggunakan bahasa Indonsia. Pada sidang itu pula, 
Ir.Sukarno mencetuskan idenya tentang dasar-dasar Negara yang dikenal dengan Pancasila. Itu artinya, bahasa Indonesia semakin kuat berfungsi sebagai alat perjuangan menuju Indonesia merdeka. Dasar-dasar Negara Indonesia merdeka dibicarakan dalam sidang tersebut (Pusat, 1995).

Uraian di atas menunjukkan betapa penggunaan bahasa Indonesia semakin meluas mempengaruhi masyarakat Indonesia, yang selanjutnya menggunakan bahasa sebagai alat dan symbol perjuangan bangsa, memberi pengaruh besar pada pemuda di zamannya. Pihak pemerintah Belanda dan Jepang pun tampak berpikir panjang dalam mengatasi persoalannya.

Selanjutnya berbagai karya tulis, dibuat dengan menggunakan bahasa Indonessia, dan buku-buku berbahasa Belanda semakin diabaikan, tidak berlaku lagi. Keadaan demikian menunjukkan, betapa kekuatan bahasa persatuan itu memiliki pengaruh pada gerakan perjuangan mengusir penjajahan. Bahasa Indonesia semakin berkembang, berpengaruh dan pada masa kemerdekaan di sekolahsekolah mulai diajarkan bahasa Indonesia dengan lebih baik, setiap anak sekolah menggunakan bahasa Indonesia sebagai pengantar belajar. Penggunaan bahasa Indonesia semakin meluas mempengaruhi cara berbahasa masyarakat dan bahasabahasa daerah Nusantara memperkaya khasanah bahasa Indonesia.

\section{SIMPULAN}

Memperhatikan uraian di atas, tampak bahwa sejak awal kemunculannya, bahasa Indonesia telah menjadi alat pemersatu, symbol bangsa Indonesia berdaulat. Meski banyak bahasa di Indonesia dan luas penggunaannya, seperti bahasa Jawa, namun ia tidak dapat menjadi bahasa persatuan Indonesia. Hal itu tidak lepas dari konteks historis dan intensitas penggunaannya dalam berkomunikasi antar penduduk di kepuauan. Maka sebagai catatan akhir dapat disampaikan sebagai berikut.

Bahwa munculya bahasa Indonesia, tidaklah persoalan tiba-tiba, atau cepat. Tetapi itu merupakan suatu proses panjang untuk menjadi bahasa Indonesia. Itu bersumber dari bahasa Melayu yang banyak digunakan sebagai alat berkomunikasi dalam hubungan perdagangan di kepulauan. Bahasa Melayu disebut sebagai lingua franca atau bahasa penghubung antar penduduk di kepulauan, yang dikunjungi banyak orang dalam hubungan perdagangan. Bahasa Melayu telah lama digunakan dan meresap pada orang-orang dari berbagai suku, etnik, budaya yang berbeda, seperti: Jawa, Sumatera, Sulawesi, Bali, Madura, Kalimantan, Ambon, dan lain-lain. Dengan beegitu, bahasa Melayu telah mempersatukan cara berkomunikasi penduduk di kepulauan. Ketika Kongres Pemuda Indonesia berlangsung di tahun 1928, bahasa Melayu muncul sebagai bahasa yang menyatukan sikap kebersamaan bangsa Indonesia. Demikian, bahasa Indonesia sebagai bahasa nasional, asal-usulnya bersumber dari bahasa Melayu.

Bahwa bahasa Indonesia, sejak awal kemunculannya di tahun 1928 sudah dimengerti sebagai bahasa alat perjuangan bangsa. Sumpah Pemuda tahun 1928, menjadi titik tolak perjuangan bangsa bersatu. Di sana bahasa Indonesia mendapatkan pijakan sebagai bahasa perjuangan, membangun sentimen kelompok, mempersatukan rasa untuk berjuang menjadi satu bangsa. Banyak likaliku perjuangan yang dialami masyarakat dalam usaha mengembangkan bahasa Indonesia, seperti larangan menggunakan bahasa Indonesia oleh aparat pemerintah kolonial, dan lain-lain. Bahasa Indonesia muncul sebagai alat perjuangan, alat komunikasi, juga sebagai symbol nasional dalam mempersatukan 
bangsa Indonesia.

Sebagai dampaknya, bahwa bahasa Indonesia telah mempengaruhi sikap masyarakat, bangsa dalam mengahadapi penjajahan. Masyarakat mulai menggalakkan penggunaan bahasa Indonesia di masyarakat, di sekolah, dan menggunakan bahasa Indonesia dalam berbagai pertemuan formal dan tidak formal. Masyarakat menentang menggunakan bahasa Belanda yang sebelumnya diwajibkan. Bahasa-bahasa daerah Nusantara memperkaya khasanah penggunaan bahasa Indonesia. Masyarakat melawan untuk menggunakan bahasa Indonesia sebagai bahasa persatuan. Masyarakat merasa bersatu dengan bahasa yang satu, bahasa Indonesia. Demikian bahasa Indonesia seJak masa kemunculan dan peralanannya, tidak lepas atau erat hubungannya dengan perjuangan bangsa Indonesia.

\section{DAFTAR PUSTAKA}

Amran, H. (1976). Fungsi dan Kedudukan Bahasa Indonesia. Jakarta.

Bawa, I. W. (1980). menulis buku dengan judul, Sejarah, Fungsi, dan Kedudukan Bahasa Indonesia. Denpasar.

Koentjaranirat. (1975). Pengembangan Bahasa Indonesia Sebagai Unsur Kebudayaan Nasional. In Bahasa dan Sastra. Jakarta.

M.D, A. H. (1978). Renungan Perjuangan Bangsa, Dulu dan Sekarang. Jakarta: Yayasan Idayu.

Pusat, Y. (1995). Sejarah Lahirnya Pancasila. Jakarta.

Sibarani, R. (2008). Pelestarian Bahasa dan Aksara sebagai Jatidiri dalam Meningkatkan Kesejahteraan Masyarakat. In Industri Budaya, Budaya Industri (pp. 639-652). Jakarta.

Usman, Z. (1975). Bahasa Melayu Sebelum dan Sesudah Menjadi Lingua Franca. Jakarta: Yayasan Idayu.

Yayasan Gedung-gedung Bersejarah Jakarta. (1978). Bunga Rampai Sumpah Pemuda. Jakarta: PN. Balai Pustaka. 